\title{
Interactive effects of radiation, temperature and salinity on different life history stages of the Arctic kelp Alaria esculenta (Phaeophyceae)
}

\author{
Jana Fredersdorf $\cdot$ Ruth Müller $\cdot$ Susanne Becker $\cdot$ \\ Christian Wiencke $\cdot$ Kai Bischof
}

Received: 28 August 2008 / Accepted: 3 March 2009 / Published online: 29 March 2009

(C) Springer-Verlag 2009

\begin{abstract}
To estimate the potential effects of climate change on polar marine macroalgae, studies on interactive stress effects of multiple climate-related parameters are essential. Interactions of temperature, radiation and salinity on two different life history stages of Alaria esculenta (L.) Greville from the Kongsfjord (Spitsbergen) were investigated for the first time within this study. Adult macroscopic sporophytes of A. esculenta were exposed to different temperatures between 4 and $21^{\circ} \mathrm{C}$ combined with artificial irradiation conditions [photosynthetically active radiation, ultraviolet (UV) radiation: UV-A/UV-B, first experiment] and with different salinities [34, 28, 20 practical salinity units (p.s.u.), second experiment]. Effects of photosynthetic activity were determined by measuring variable chlorophyll fluorescence of photosystem II. Germination success of young microscopic zoospores of A. esculenta was studied under multifactorial stress. Zoospore suspensions were exposed to the three different salinities and irradiation conditions at four temperatures between 2 and $16^{\circ} \mathrm{C}$. Overall, A. esculenta exhibited a highly stagespecific susceptibility towards the experimental treatments.
\end{abstract}

Communicated by Kouki Hikosaka.

J. Fredersdorf $(\varangle) \cdot$ S. Becker $\cdot$ K. Bischof

Department of Marine Botany, University of Bremen,

Leobener Strasse NW2, Bremen, Germany

e-mail: Jana.Fredersdorf@awi.de

J. Fredersdorf $\cdot$ S. Becker $\cdot$ K. Bischof

Center for Tropical Marine Ecology,

Fahrenheitstrasse 6, 28359 Bremen, Germany

J. Fredersdorf $\cdot$ R. Müller $\cdot$ C. Wiencke

Section Seaweed Biology, Alfred Wegener Institute for Marine und Polar Research (AWI), Am Handelshafen 12,

27570 Bremerhaven, Germany
In both experiments using sporophytes, photosynthetic activity showed significant temperature effects and only very few significant radiation and salinity effects. Microscopic stages of A. esculenta were shown to be more sensitive than the adult macroscopic stages, since germination capacity of zoospores was significantly affected by temperature and salinity changes, and interactions of both. These results suggest that multiple stress factors interact synergistically. Temperature seems to be a predominant environmental parameter for the kelp A. esculenta. Overall, A. esculenta proved to be relatively tolerant and adaptable to increasing temperature and UV radiation, as well as to diluted salinities, but only up to a specific limit.

Keywords Climate change - Germination - Life cycle · Multiple stress · Photosynthesis

\section{Introduction}

Kelp forests are phyletically diverse, structurally complex and highly productive components of coldwater rocky marine coastlines (Steneck et al. 2002). They act as food, habitat and nursery for multiple associated organisms. Light, temperature, nutrients, water movement and salinity primarily control the growth and distribution of marine algae (Kirst 1990). Due to their enormous importance within coastal ecosystems, a decrease in seaweed abundance will have dramatic consequences for the sum of associated organisms (Bischof et al. 2006). Climate change has caused measurable temporary effects on kelps near their thermal limit (Steneck et al. 2002). The Fourth Assessment Report of the United Nations Intergovernmental Panel on Climate Change (IPCC 2007) shows that warming of the climate system is unequivocal and has occurred in both the 
Northern and Southern Hemispheres and across the oceans. The high scenario of the IPCC report (2007) predicts that the annual Arctic surface temperatures north of $60^{\circ} \mathrm{N}$ will increase in the range of $2.4-6.4^{\circ} \mathrm{C}$ by 2100 . Furthermore, the increased temperature of the Arctic Ocean, including Spitsbergen, will lead to earlier ice melt and later freeze-up within the yearly cycle, increases in precipitation, a decrease in sea-ice cover with a decrease of ocean salinity in the upper $500 \mathrm{~m}$, and increased UV radiation resulting from stratospheric ozone depletion (ACIA 2005; IPCC 2007). Changes affect macroalgae, plankton, fish and zooplankton, especially due to rising water temperatures and changes in salinity, oxygen levels and water circulation.

Physiochemical changes due to climate change are happening most rapidly in polar regions. Thus, they are considered as a sensitive barometer for processing climate change. Environmental variables are changing simultaneously worldwide, as different abiotic factors are acting in combination and interdependently. Our interest was to study the interactive effects of multiple abiotic stressors on Arctic marine macroalgae to understand parts of stress physiology and to estimate the ecological implications.

In recent years, the marine coastal ecosystem of the Arctic Kongsfjord was intensively studied and serves currently as a model ecosystem and monitoring site for the effects of climate change in the Arctic (Svendsen et al. 2002; Wiencke 2004a). The underwater flora is composed of at least 50 different macroalgal species (Wiencke et al. 2004b). In the mid sublittoral the brown algae Laminaria digitata, Saccharina latissima and Alaria esculenta are the key species of the dominant kelp forests.

Alaria esculenta (L.) Greville, a large brown seaweed, is a member of the Alariaceae and belongs to the Laminariales (kelp) which populates sublittoral zones of Arctic and cold temperate coastal ecosystems (Lüning 1990). The regional distribution of A. esculenta is temperature controlled (Munda and Luening 1977); it is present in the North Pacific as well as in the North Atlantic, and is absent from the southern North Sea and English Channel due to high summer water temperatures which exceed $16^{\circ} \mathrm{C}$ (Munda and Luening 1977, Lüning 1990). A. esculenta has a heteromorphic diplohaplontic life history. The thallus of A. esculenta is characterized by an upright stipe and a long blade with a midrib. The morphology of lamina and stipe can vary widely between specimens due to wave exposure (Sundene 1962).

In the Kongsfjord, A. esculenta can be found between 3- and 10-m depth (Bischof et al. 1998). Earlier physiological studies on this species proved that sporophytes of A. esculenta have a certain potential to acclimate effectively to increasing levels of both photosynthetically active radiation (PAR) and moderate ultraviolet (UV) radiation fluence (Bischof et al. 1998; Bischof et al. 1999; Roleda et al.
2005). Under ambient solar radiation, the germination and UV tolerance of zoospores was highest in the shallow water species Saccorhiza dermatodea, intermediate in the sublittoral A. esculenta and lowest in the upper-to-mid sublittoral L. digitata (Wiencke et al. 2006). While UV-damaging effects on seaweed physiology in single-factor experiments are well studied (reviewed by Franklin and Forster 1997; Bischof et al. 2006; Roleda et al. 2007; Wiencke et al. 2007a), the physiological studies on interactive effects of multiple abiotic stressors are scarce (but see Hoffman et al. 2003; Müller et al. 2008; Steinhoff et al. 2008). Moreover, early developmental stages are known to be most susceptible to environmental stress (Roleda et al. 2007), but there are only very few studies on interactions of several abiotic stressors on microscopic life stages of Laminariales (Hoffman et al. 2003; Müller et al. 2008; Steinhoff et al. 2008). The purpose of the present study is to explore the interactive effects of abiotic environmental factors on the kelp A. esculenta. In particular, we identify the effects and interactions of temperature, radiation and salinity and test potential physiological tolerance limits on two different life history stages of A. esculenta from Spitsbergen.

\section{Materials and methods}

Study site

The Kongsfjord presents a marine coastal ecosystem located at the northwestern coast of Spitsbergen $\left(78^{\circ} 55^{\prime} \mathrm{N}\right.$, $11^{\circ} 56^{\prime} \mathrm{E}$, Svalbard, Norway). During spring and early summer, the fjord is generally free of ice, the water is clear, and thus, its transparency to UV radiation is very high. These factors are combined with relatively low air temperatures at that time (Hanelt et al. 2001). With increasing air temperature in the summer (about $5^{\circ} \mathrm{C}$ ), snow layers and glacier ice melt and cause a high discharge of turbid fresh water and sediments into the fjord. In general, the local water mass has a salinity of about 34.5 practical salinity units (p.s.u.) in the spring and drops below 28 p.s.u. in the surface water near the glacier in the summer, whereas the seawater temperature increases and varies by about $4{ }^{\circ} \mathrm{C}$ in the summer (Hanelt et al. 2001; Svendsen et al. 2002).

Algal material

In June 2005 and early August 2006 sporophytes of A. esculenta were collected by Scuba divers in the Kongsfjord in the vicinity of Ny Ålesund and transported to the laboratory in black plastic containers. For bi-factorial experiments with sporophytes of A. esculenta, 14 individuals were collected at depths of about 7-9 $\mathrm{m}$ (experiment I) and ten individuals at 9-10 $\mathrm{m}$ (experiment II), respectively. After 
Table 1 Experimental conditions of irradiance, temperature and salinity with exposure time during the studies on interactive effects on different life cycle stages of Alaria esculenta

\begin{tabular}{|c|c|c|c|c|c|}
\hline \multirow[t]{2}{*}{ Life cycle stage } & \multicolumn{2}{|l|}{ Radiation } & \multirow[t]{2}{*}{ Temperature $\left({ }^{\circ} \mathrm{C}\right)$} & \multirow[t]{2}{*}{ Salinity (p.s.u.) } & \multirow[t]{2}{*}{ Exposure time } \\
\hline & $\overline{\operatorname{PAR}\left(\mu \mathrm{mol} \mathrm{m}{ }^{-2} \mathrm{~s}^{-1}\right)}$ & $\overline{\mathrm{UV}}\left(\mathrm{W} \mathrm{m}^{-2}\right.$, unweighted) & & & \\
\hline Sporophyte $(n=14)$ & $46( \pm 8)$ & $\begin{array}{l}\text { UV-A: } 7( \pm 1) \\
\text { UV-B: } 0.3( \pm 0.07)\end{array}$ & $4,9,13,17,21( \pm 1)$ & & 6 days \\
\hline Sporophyte $(n=10)$ & $80( \pm 10)$ & & $4,8,15( \pm 1)$ & $34,28,20$ & 6 days \\
\hline Zoospore & & & & $33,26,20$ & Short \\
\hline \multirow[t]{2}{*}{ Zoospore } & $20( \pm 2)$ & $\begin{array}{l}\text { UV-A: } 4.5( \pm 0.5) \\
\text { UV-B: } 0.4( \pm 0.04)\end{array}$ & & & $8 h+6$ days \\
\hline & Dim light (6-10) & & $2,7,12,16( \pm 1)$ & $34,28,20$ & \\
\hline
\end{tabular}

PAR Photosynthetically active radiation, p.s.u. practical salinity units

cleaning of sporophytes, several 30-mm-diameter algal discs were cut right beside the midrib and seven discs from the mixture of all discs were exposed in each 1,000-ml plastic beaker (Vitalab, Germany). Each beaker was permanently equipped with a bubble stone connected to a selfpriming pump in order to provide water circulation and permanent movement of the alga discs. Seawater in the beakers was exchanged on the fourth experimental day. The defined abiotic factors, radiation, temperature and salinity, were uniformly distributed across the experimental area and across treatments in all set-ups. To determine the vulnerability of zoospores, individuals of A. esculenta with fertile sporophylls were sampled by means of Scuba diving at 4- to 8-m depth in July 2007. Sori from mature sporophylls were cut, cleaned and dried with tissue paper, as well as stored in a dark moist chamber at $2^{\circ} \mathrm{C}$ over 1-2 nights. To induce the release of zoospores, sori were subsequently immersed in $0.2 \mu \mathrm{m}$ filtered seawater $\left(7^{\circ} \mathrm{C}\right)$ for a maximum of $30 \mathrm{~min}$. After removal of sori, zoospore suspensions were filtered through $20-\mu \mathrm{m}$ gauze (Nytal HD 20; HydroBios, Germany).

Bi-factorial experimental set-ups for sporophytes

In the first laboratory experiment, algal material was exposed to artificial UV radiation at defined temperatures for the duration of 6 days. The beakers containing algal discs were placed in temperature-controlled water tanks $(648 \times 846 \times 160 \mathrm{~mm}, 39$ l; Bürkle, Germany). The temperature in each tank was controlled by cryostats (model 1160S; VWR International, Germany) and monitored by temperature loggers (testo 175-T1; Testo, Lenzkirch, Germany) and by digital probe thermometer in each beaker. (TFA Dostmann, Germany). Two tanks were established for each of the five temperatures applied. For each temperature three beakers with foils for each of the three radiation conditions were randomly distributed in the two tanks. A set of 15 light tubes provided permanent uniform irradiation above the tanks: nine tubes (true light II, $36 \mathrm{~W}$; Powertwist, USA) emitted PAR and six fluorescent tubes (UV A-340 tubes, $40 \mathrm{~W}$; Q-Panel, USA) UV radiation. Irradiance was measured with a LI-190 quantum sensor connected to a LI-250 light meter (LI-COR, Lincoln, USA) and a UV radiometer PMA2100 (Solar Light, USA). The adjusted temperatures and irradiation conditions are detailed in Table 1. In order to generate three radiation treatments with and without UV radiation, the beakers containing alga discs were shielded with different cut-off foils. Foils were transparent to wavelengths of: (1) 400-700 nm (URUV Ultraphan UV farblos; Difrega, Germany) for PAR treatments (P); (2) 320-700 nm (Folanorm SF-AS; Folex, Germany) for PAR + UVA (PA) treatments; and (3) 295-700 nm (URT140 Ultraphan UV farblos; Difrega) for PAR + UVA + UVB (PAB) treatments. The respective transmission spectra of these cut-off foils are shown in Bischof et al. (2002).

In the second laboratory experiment, algal discs were exposed to different, artificially produced salinities at defined temperatures for 6 days. The basic experimental set-up was the same as in the first experiment, but the radiation conditions and the ambient salinities of the samples were changed (see Table 1). Above the tanks only PAR irradiance (15 light tubes) was provided. Algal discs were exposed to three different salinities in separate beakers. These were diluted by mixing fjord water with MilliQ water and defined by a hand-held refractometer (ATAGO, Tokyo).

Photosynthetic measurements of sporophytes

Photosynthetic activity of samples from the two experiments was determined by measuring in vivo chlorophyll fluorescence of photosystem II (PS II) using a PAM 2100 chlorophyll fluorometer (Walz, Effeltrich, Germany) as described by Hanelt et al. (1997). The maximal quantum yields of photosynthesis $(F \mathrm{v} / F \mathrm{~m})$ as an indicator of the physiological status of the blades (Schreiber et al. 1994 for details) was measured initially and after 1,2 , and 5 days of exposure. The experiments were arranged in a split-plot design with repeated measures and three to five replications. 
Mean values and SDs were calculated from the replicates per treatment. Results were analysed using a two-way ANOVA with repeated measures on the two factors and their interactions. Statistically significant differences and interactions of means were compared with the post hoc Tukey test [honest significant difference (HSD)] at $P<0.05$ (Sokal and Rohlf 1995). All statistical analysis with data from sporophytes was performed using the commercial software JMP 6 (SAS Institute, Cary, N.C.).

\section{Photosynthetic measurements of zoospores}

Mixed zoospore suspensions from five individuals were diluted with distilled water to different salinities (see Table 1; Cond 340i, sensor TetraCon 325, WTW, Germany) to determine the photosynthetic efficiency of zoospores. After darkening the suspensions for $3 \mathrm{~min}$, the $\mathrm{Fv} /$ $F \mathrm{~m}$ was calculated in four (experiment I, salinity 20, 26, 33 p.s.u.) or five (experiment II, salinity 20, 33 p.s.u.) replicates using a Water-PAM (Walz, Germany). Data of each experiment were tested for homogeneity with the Levene test, and means were compared by a one-factorial ANOVA including the post hoc Tukey test. In addition, $F \mathrm{v} / F \mathrm{~m}$ values from zoospore suspensions at salinity 33 p.s.u. from two experiments were statistically tested with Levene's test $(P<0.01)$ and a $t$-test $(P<0.05)$. All statistical analysis with data from zoospores was conducted in accordance with Sokal and Rohlf (1995) with the software Statistica version 7 (StatSoft, USA).

\section{Germination capacity of zoospores}

To study germination success, separate zoospore suspensions obtained from five individual sporophylls were adjusted to three different salinities (see Table 1) with distilled water. In parallel, the numbers of zoospores in suspensions were counted with a Neubauer chamber (Brand, Germany) under 200-fold magnification using an Axioplan microscope (Zeiss, Germany). Suspensions were allotted by dispensettes (Brand, Germany) into $35 \times 10$-mm culture dishes (Corning, USA) containing two cover slips each ( $25 \pm 1$ zoospores $\mathrm{mm}^{-2}$ after settlement). Subsequently, suspensions with different salinities were exposed in culture dishes covered with cut-off foils to generate the different radiation treatments $(\mathrm{P}, \mathrm{PA}, \mathrm{PAB})$ in climate chambers run at four temperatures (see Table 1). After $8 \mathrm{~h}$ of UV exposure, and 6 days of UV recovery at dimmed PAR $\left(6-10 \mu \mathrm{mol} \mathrm{m}{ }^{-2} \mathrm{~s}^{-1}\right)$ under constant temperatures and salinity, the percentage of germination was ascertained from 300 spores per replicate under 200- or 400-fold magnification using an Axioplan microscope (Zeiss, Germany). Using this method the germinated spores possessing a germination tube were distinguished from dead and living cells without germination tubes (for details see Müller et al. 2008). Percentage data were arcsine transformed and homogeneity of variances was tested with Cochran's test $(P<0.01)$ prior to testing data with a three-factorial ANOVA $(P<0.05)$ and post hoc Tukey's test (HSD, $P<0.05)$.

\section{Results}

Photosynthesis of sporophytes

Our first results demonstrate the interactive effects of two combined stress factors: radiation/temperature and salinity/ temperature on sporophytes of A. esculenta (Figs. 1, 2). In both experiments the maximum quantum yield of photosystem II $(F \mathrm{v} / F \mathrm{~m})$ showed pronounced significant temperature effects, but only little, but still significant, radiation or salinity effects. There was no significant interaction between the combined abiotic factors.

The responses of sporophytes of A. esculenta to different combinations of temperature and radiation conditions over 6 days are shown in Fig. 1. There was a significant effect of time $(F=12.97, P<0.0001)$ with $F \mathrm{v} / F \mathrm{~m}$ decreasing over time. Furthermore, the main effect of temperature $(F=19.33, P<0.001$; Fig. 1$)$ and the time at temperature interaction $(F=7.25, P<0.001)$ were both highly significant. Initial values of $F \mathrm{v} / F \mathrm{~m}$ were $0.66 \pm 0.04$ (day 1; Fig. 1). By the second day of exposure a decrease in $F \mathrm{v} / F \mathrm{~m}$ was observed at 4,9 and $21^{\circ} \mathrm{C}$ with the strongest inhibition with an $F \mathrm{v} / F \mathrm{~m}$ of $0.26 \pm 0.02$ occurring under the $\mathrm{PAB}$ treatment at $4{ }^{\circ} \mathrm{C}$ on day 6 (Fig. 1). At higher temperatures, i.e. 13 and $17^{\circ} \mathrm{C}, F \mathrm{~V} / F \mathrm{~m}$ values were constant over 3 days of exposure and decreased only on day 6 (Fig. 1). Maximum quantum yields after 2 days of recovery at approximately $5^{\circ} \mathrm{C}$ and dim light were consistent with values measured at day 6, or showed an upward trend (data not shown). However, under the highest temperature of $21^{\circ} \mathrm{C}$, $F \mathrm{v} / F \mathrm{~m}$ decreased rapidly (Fig. 1), algal discs bleached, disintegrated and died after 3 days of exposure.

On the second day of exposure (Fig. 1), the $F \mathrm{v} / F \mathrm{~m}$ of the algae at 4 and $21^{\circ} \mathrm{C}$ were significantly lower than those at the other temperatures $(P<0.001)$. Also after 3 days of exposure, the $\mathrm{Fv} / \mathrm{Fm}$ of algal treatments at $4^{\circ} \mathrm{C}$ were significantly lower than those of the treatments at 13 and $17^{\circ} \mathrm{C}$ $(P<0.001)$, and the $F \mathrm{v} / F \mathrm{~m}$ of algal treatments at $9^{\circ} \mathrm{C}$ were significantly lower than those of the treatments at $13^{\circ} \mathrm{C}$ $(P<0.001)$. However, the lowest $F \mathrm{v} / F \mathrm{~m}$ was that of bleached and thin alga discs at $21^{\circ} \mathrm{C}$ on the third day $(P<0.001)$. The individual effect of radiation on $F \mathrm{v} / F \mathrm{~m}$ of A. esculenta sporophytes was significant $(F=4.38$, $P=0.022)$, as well as the interaction of radiation with time $[F(6,56)=2.92, P=0.015]$. Significant inhibition of $F \mathrm{v} / F \mathrm{~m}$ 




Fig. 1 Maximum quantum yield of photosystem II $(F \mathrm{v} / F \mathrm{~m})$ of the vegetative lamina of Alaria esculenta at five temperatures $(4,9,13,17$, $21^{\circ} \mathrm{C}$ ) and three radiation conditions [photosynthetically active radiation $(P A R)$ treatments $(P$; grey bars $)$; PAR + ultraviolet (UV)-A $(P A ;$ white bars $) ; \mathrm{PAR}+\mathrm{UVA}+\mathrm{UVB}(P A B ;$ black bars $)]$, measured



over 6 days of exposure. SDs are represented by vertical bars $(n=3)$. Different letters indicate significant temperature differences $(P<0.05)$ between treatments on the respective measuring dates, and stars indicate significant radiation effects $(P<0.05)$ between treatments



Fig. $2 F \mathrm{v} / F \mathrm{~m}$ of the vegetative lamina of A. esculenta at three temperatures $\left(4,8,15^{\circ} \mathrm{C}\right)$ and three salinities $(34$ p.s.u. = black bars, 28 p.s.u. $=$ grey bars, 20 p.s.u. $=$ white bars $)$, measured over 6 days of

by radiation was observed in algae exposed to the whole light spectrum (PAB) at lower temperatures of 4 and $9{ }^{\circ} \mathrm{C}$ (stars in Fig. 1). On the second day of exposure the $F \mathrm{v} / F \mathrm{~m}$ of specimens under the $\mathrm{PAB}$ treatment at $4^{\circ} \mathrm{C}$ were significantly lower than under the $\mathrm{P}$ treatment at $4^{\circ} \mathrm{C}(P=0.017)$, and the $F \mathrm{v} / F \mathrm{~m}$ of specimens under the PAB treatment at $9^{\circ} \mathrm{C}$ were lower than under the $\mathrm{P}$ and the PA treatments at $9^{\circ} \mathrm{C}(P=0.002)$, respectively. However, there were no interactive effects of temperature and radiation within the experiment $(P=0.191)$.

The maximum quantum yield of photosynthesis $(F \mathrm{v} / F \mathrm{~m})$ over 6 days at combined temperature $\left(4-15^{\circ} \mathrm{C}\right)$ and salinity conditions (34, 28 and 20) decreased over time (Fig. 2). All initial values (day 1 ; Fig. 2) of $F \mathrm{v} / F \mathrm{~m}$ were $0.713 \pm 0.013$, then decreased on day 2 and were constant during the following days. In addition, there was a significant individual effect of temperature $[F(2,18)=5.56, P=0.013]$ and a significant time by temperature interaction $(F=3.22$,

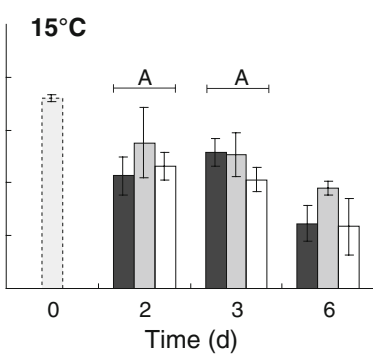

exposure. SDs are represented by vertical bars $(n=3)$. Different letters indicate significant differences $(P<0.05)$ between treatments on the respective measuring dates. For abbreviations, see Fig. 1

$P=0.014$ ). Post hoc analysis (Fig. 2) revealed that $F \mathrm{v} / F \mathrm{~m}$ of algae at $15^{\circ} \mathrm{C}$ on day 2 was significantly higher than at $8^{\circ} \mathrm{C}(P=0.020)$. Furthermore on day $3, F \mathrm{v} / F \mathrm{~m}$ of algae at $15^{\circ} \mathrm{C}$ was significantly higher than at 8 and $4^{\circ} \mathrm{C}(P=0.002)$ (Fig. 2). Nonetheless, the results of the two-way ANOVA with repeated measures did not show interactive effects of temperature and salinity $(P=0.130)$, of temperature, time and salinity $(P=0.151)$ nor of time and salinity $(P=0.064)$. Moreover, only one significant individual effect of salinity $(F=4.51, P=0.026)$ was found by post hoc analysis on day 6 , as the total $F \mathrm{v} / F \mathrm{~m}$ of algae in diluted salinity of 28 was significantly higher than at the fjord salinity of 34 p.s.u. $(P=0.018)$.

Photosynthesis of zoospores

$F \mathrm{v} / F \mathrm{~m}$ values of $0.39 \pm 0.06$ were measured in zoospores of A. esculenta exposed to three salinities of 20,26 and 


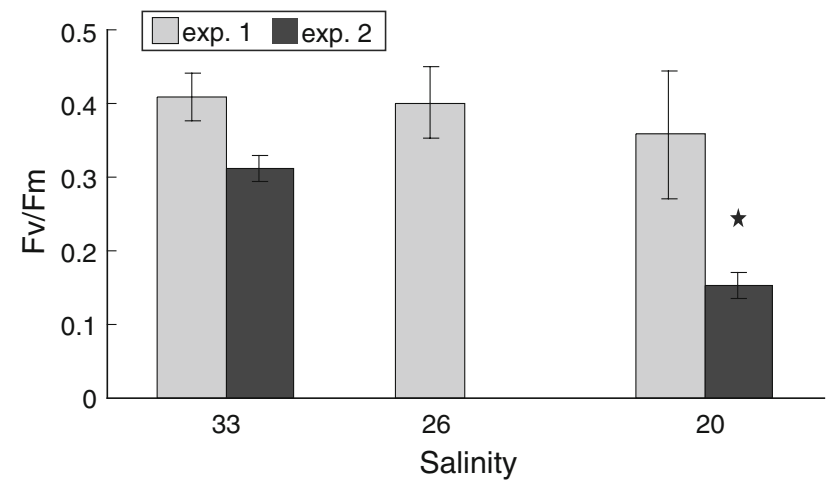

Fig. $3 \mathrm{Fv} / F \mathrm{~m}$ of freshly released zoospore suspensions of A. esculenta at different salinities $(33,28,20$ p.s.u.) after the first $(n=4$, grey bars) and second ( $n=5$, black bars) experimental runs. SDs are represented by vertical bars $(n=4 / 5)$, and stars indicate significant salinity effects $(P<0.05)$. For abbreviations, see Fig. 1

33 p.s.u. (Fig. 3, grey bars). No significant differences among salinity treatments were detected $(P \geq 0.05)$. In a second experiment, photosynthesis of zoospores at ambient salinity of 33 p.s.u. decreased significantly to an $F \mathrm{v} / \mathrm{Fm}$ value of $0.31 \pm 0.02$ compared to the first experiment $(P<0.001)$, due to unidentified environmental influences (Fig. 3, black bars). Moreover, during the second experiment $F \mathrm{v} / F \mathrm{~m}$ measured in zoospores treated at low salinity (20 p.s.u.) was inhibited to $0.15 \pm 0.02$ (to $50 \%$ ), and thus it was significantly different to that of zoospores under ambient salinity conditions of 33 p.s.u. $(P<0.001)$.

\section{Germination of zoospores}

Germination rates of zoospores after $8 \mathrm{~h}$ of UV exposure and 6 days of post-culture varied with temperature and salinity (Fig. 4). Maximally 70-80\% of zoospores of A. esculenta germinated at $7^{\circ} \mathrm{C} / \mathrm{ambient}$ salinity (34 p.s.u,) and at $12^{\circ} \mathrm{C}$ /moderate salinity (28 p.s.u,) under all radiation conditions (Fig. 4). Nevertheless, the germination of zoospores was significantly impaired by temperature $(F=35.73$, $P \leq 0.001)$ and salinity treatments $(F=50.84, P \leq 0.001)$ and their interaction $(F=2.33, P=0.035)$. Zoospores exposed to salinities of 34 and 28 p.s.u, at $2-12^{\circ} \mathrm{C}$ were significantly different from the control (P treatment) at the low salinity of 20 p.s.u, at $16^{\circ} \mathrm{C}(P \leq 0.03)$, where only $30 \%$ zoospores germinated. On the other hand, zoospores exposed to $\mathrm{P}$ treatment and low salinity $(20$ p.s.u, $)$ at $2-7^{\circ} \mathrm{C}$ achieved a maximum of $46-48 \%$ germination and $61 \%$ germination at $12^{\circ} \mathrm{C}$, and were equivalent to other salinitytreated controls in this temperature range $(P \geq 0.05)$. Similarly, the germination of PA- and PAB-treated zoospores at $2-12^{\circ} \mathrm{C}$ was $46-75 \%$ (Fig. 4) and did not differ between salinity treatments or radiation treatments in the same temperature range $(P \geq 0.05)$. Likewise $\mathrm{PA}$ - and $\mathrm{PAB}$-treated
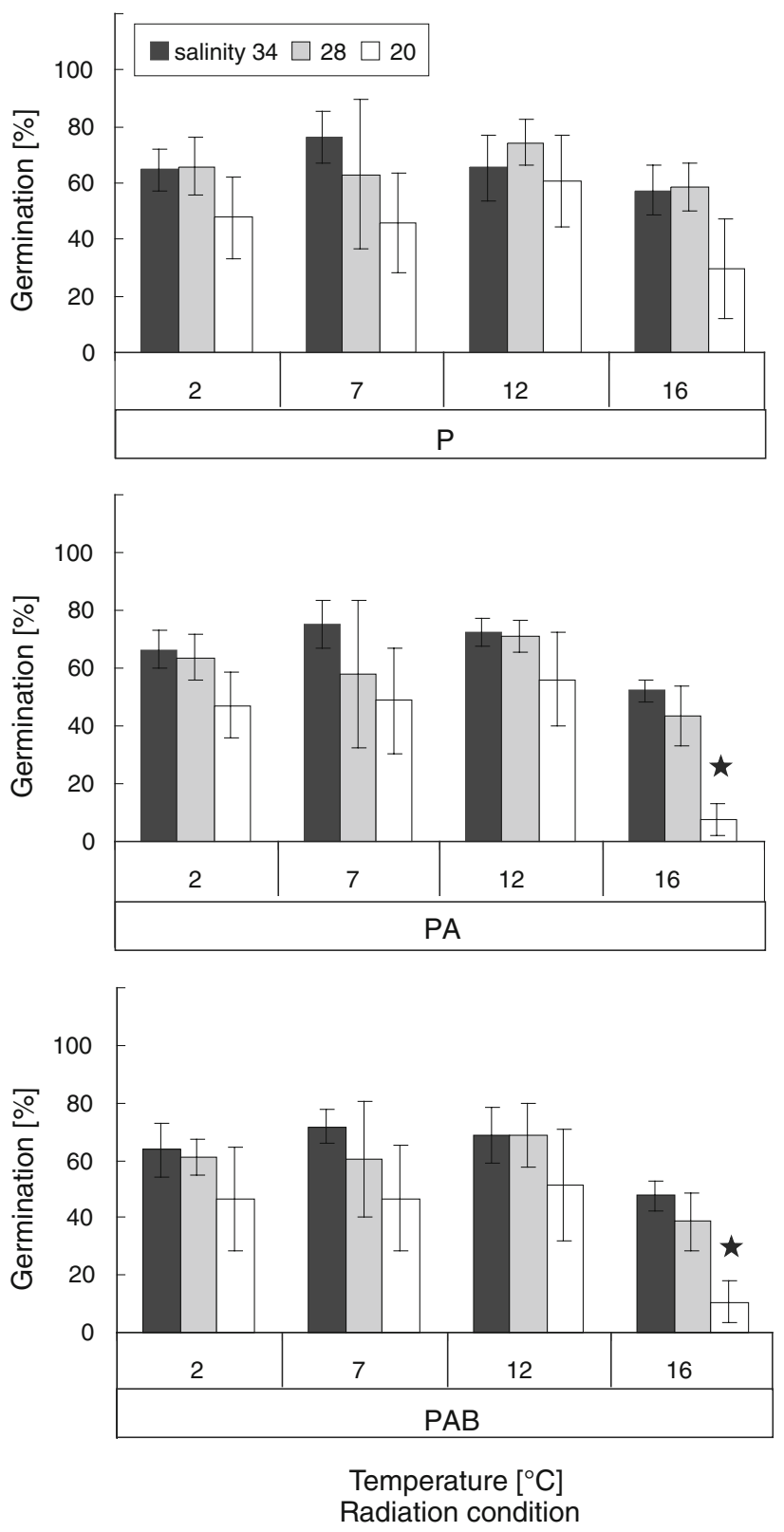

Fig. 4 Germination rates of A. esculenta zoospores (expressed in percentage of control), ascertained after $8 \mathrm{~h}$ of radiation exposure (P, PA, $\mathrm{PAB}$ ) and 7 days of UV recovery below dim light at constant temperature $\left(2,7,12,16^{\circ} \mathrm{C}\right)$ and salinity conditions (34 p.s.u, = black bars, 28 p.s.u, = grey bar, 20 p.s.u, = white bars $).$ SDs are represented by vertical bars $(n=3)$, and stars indicate interactive effects of temperature and salinity $(P<0.05)$. For abbreviations, see Fig. 1

zoospores exposed to ambient salinity (34) at $16^{\circ} \mathrm{C}$ revealed $48-52 \%$ germination, and were not different from $\mathrm{P}, \mathrm{PA}$ and $\mathrm{PAB}$ treatments exposed to the three salinity conditions at $2-12^{\circ} \mathrm{C}(P \geq 0.05)$.

However, germination of PA- and PAB-treated zoospores at diluted salinities of 28 and 20 p.s.u. was strongly inhibited by the high temperature of $16^{\circ} \mathrm{C}$. The germination decreased to $38-43 \%$ ( 28 p.s.u.) or $7-11 \%$ ( 20 p.s.u.), 
respectively. In detail, germination of $\mathrm{PA} / 16^{\circ} \mathrm{C}$-treated zoospores at a salinity of 20 p.s.u. (Fig. 4, star) differed significantly from germination of $\mathrm{PA} / 16^{\circ} \mathrm{C}$-treated zoospores at ambient salinity of 34 p.s.u. $(P \leq 0.001)$, and from those spores exposed to all other salinity and radiation treatments at $2-12^{\circ} \mathrm{C}(P \leq 0.019)$. Within PAB-treated zoospores at $16^{\circ} \mathrm{C}$, significant differences were likewise obtained between germination under ambient (34 p.s.u.) and diluted (20 p.s.u.) salinities $(P \leq 0.001)$. Moreover, germination of PAB-treated zoospores at $16^{\circ} \mathrm{C}$ and salinity of 20 p.s.u. (Fig. 4, star) differed significantly to that of exposed zoospores at $12^{\circ} \mathrm{C}$ and all salinities $(P \leq 0.006)$. Overall, germination of zoospores was strongly affected by different salinities at the relatively high temperature of $16^{\circ} \mathrm{C}$ $(F=3.33, P \leq 0.04)$. However, only a significant temperature/salinity interaction could be detected $(F=2.33$, $P=0.035)$.

\section{Discussion}

This study demonstrates the importance of research on physiological responses to interactions between two or more environmental stress factors, especially with regard to ecological aspects and against the background of global climate change. It suggests that multiple stress factors interact synergistically or that one factor prevails as a single effect: photosynthetic activity of sporophytes showed significant individual effects, whereas germination capacity of zoospores was additionally affected by interactions. Similar to other studies, microscopic zoospores were shown to be more sensitive than adult macroscopic sporophytes (Dring et al. 1996; Coelho et al. 2000; Veliz et al. 2006; Wiencke et al. 2006).

\section{Temperature effects}

Photosynthesis of A. esculenta sporophytes reflected the wide range of geographical distribution (Lüning 1990) and tolerance by this alga of temperatures between 4 and $17^{\circ} \mathrm{C}$ (Figs. 1, 2). For comparison, $5^{\circ} \mathrm{C}$ is the average summer temperature of the natural environment of the algae in the investigation area (Hanelt et al. 2001), but the IPCC report (2007) predicts temperature rises of 0.5 to $1.6^{\circ} \mathrm{C}$ by 2030 , rising to 1.1 to $6.4^{\circ} \mathrm{C}$ by 2100 . Under the impact of combined temperature and radiation conditions the $F \mathrm{v} / F \mathrm{~m}$ of sporophytes under 4 and $9^{\circ} \mathrm{C}$ decreased rapidly compared to the more constant $F \mathrm{v} / F \mathrm{~m}$ values at 13 and $17^{\circ} \mathrm{C}$ (Fig. 1). Generally, the decrease in $F \mathrm{v} / F \mathrm{~m}$ is a response to diverse stress conditions of photosynthesis. Furthermore, such a decrease also suggests an activated photoprotective mechanism, dynamic photoinhibition. By rapid and reversible down-regulation of photosynthetic activity, algae protect themselves from excessive PAR (Hanelt et al. 1997). However, different degrees of $F \mathrm{v} / F \mathrm{~m}$ reduction were observed between the treatments. This indicates that the temperature optimum with efficient photosynthesis of A. esculenta sporophytes was in the range of $13-17^{\circ} \mathrm{C}$. On the other hand, germination of zoospores of $A$. esculenta exhibits a lower optimal temperature range of $2-12^{\circ} \mathrm{C}$ (Fig. 4; Müller et al. 2008). There are no data available from the literature to compare thermal optimums of different life stages of Arctic kelp species. There exist only a few temperature studies on Arctic kelp, mainly on growth at the upper or lower survival temperatures [Biebl 1970; Fortes and Lüning 1980; tom Dieck (Bartsch) 1993; Wiencke et al. 1994; Bischoff-Bäsmann 1997]. The zoospores of A. esculenta showed a lower upper survival limit (UST) for germination, less than $18^{\circ} \mathrm{C}$ after 7 days of temperature exposure (Müller et al. 2008), whereas in the present study zoospores survived $\geq 16^{\circ} \mathrm{C}$ for 6 days (Fig. 4). Similar observations have been made for sporophytes of $A$. esculenta by Munda and Luening (1977) and Sundene (1962), where temperatures of $16-17^{\circ} \mathrm{C}$ for a duration of a few weeks on Helgoland or Oslo Fjord were lethal to Alaria sporophytes. Photosynthesis of sporophytes of A. esculenta was unaffected by temperatures of $\leq 17^{\circ} \mathrm{C}$ for 6 days in the present study. Lower thermal limits for growth and higher limits for photosynthesis were often observed and are discussed in Davison (1991). The ability of algae to change phenotypically may be a reason for this discrepancy in this study.

The highest tested temperature of $21^{\circ} \mathrm{C}$, which is unrealistic under global change conditions in the Arctic, was tested to reveal the maximal temperature limit. The algal discs bleached and disintegrated quickly, which proved that temperatures over $20^{\circ} \mathrm{C}$ are lethal to sporophytes of A. esculenta. Also the most temperature-tolerant male and female gametophytes of A. esculenta revealed an UST of 19-2 $1^{\circ} \mathrm{C}$ after 8 weeks of exposure [tom Dieck (Bartsch) 1993]. Thus our physiological results agree with Widdowson (1971), who described the northerly distribution pattern of the genus Alaria with a southern limit close to the $20^{\circ} \mathrm{C}$ isotherm of maximum sea temperature.

Temperature and irradiation effects

In addition to significant temperature effects on sporophytes, there were some radiation effects (Fig. 1). Significant inhibitions by radiation conditions were only observed in sporophytes of A. esculenta exposed to the whole light spectrum under the lowest temperature. In the set-up, there was a relatively low PAR:UV ratio. UV-B irradiance, however, was similar to or higher than naturally occurring intensities. This suggests that the sensitivity of algae to additional stress factors increases at temperatures lower than the optimum growth temperatures. Hoffman et al. 
(2003) also supported the hypothesis that temperature mediates the net biological effect of UV radiation and vice versa. Gómez et al. (2001) concluded from their study on Gelidium pulchellum that increasing growth temperature might stimulate repair processes. Additionally, the UVinduced inhibition of photosynthesis was much higher in Ulva clathrata from Chile than in Ulva bulbosa from Antarctica at $0^{\circ} \mathrm{C}$, whereas temperatures of $10^{\circ} \mathrm{C}$ compensated for UV effects in both species (Rautenberger and Bischof 2006). Most of the published studies on polar kelp zoospores focus on UV effects and the impacts on germination pattern, photosynthesis and recovery after exposure (see Swanson and Druehl 2000; Roleda et al. 2006; Wiencke et al. 2007b, for reviews see Roleda et al. 2007; Wiencke et al. 2007a and references therein). There are only very few studies on interactions between temperature and UV radiation presently available. Hoffman et al. (2003) exposed early life stages of Alaria marginata and Fucus gardneri to four levels of UV radiation at three temperatures. For $A$. marginata, $10^{\circ} \mathrm{C}$ was not a limiting temperature in the absence of UV radiation, but under high levels of UV radiation spores were unable to germinate. Furthermore, Steinhoff et al. (2008) and Müller et al. (2008) illustrated that UV-B radiation and high temperatures detrimentally affected the physiology and ultrastructure of zoospores of temperate and Arctic Laminariales. This suggests that UV radiation and temperature interactions represent a general phenomenon and have important implications for studies on climate change (Hoffman et al. 2003). UV radiation and temperature had no interactive effects on the germination of zoospores in this study (Fig. 4; Müller et al. 2008) and were, in comparison to other important kelp species of the Kongsfjord, highly tolerant to both abiotic factors (Müller et al. 2008). However, it has to be taken into account that a repeated UV-B exposure of $4 \mathrm{~h}$ for 3 days or higher PAR and UV-B irradiances caused a strong impairment of germination of zoospores of Alaria (Hoffman et al. 2003; Wiencke et al. 2007b).

Temperature and salinity effects

A. esculenta sporophytes tolerated examined temperatures between 4 and $15^{\circ} \mathrm{C}$ and salinities ranging from fjord salinity 34 p.s.u. to diluted salinities of 28 and 20 p.s.u. in the second experiment, with only one significant individual effect of salinity found on day 6 (Fig. 2). In contrast, zoospores were affected by the interaction of low salinity combined with high temperature, since the germination of PA- and PAB-treated zoospores at a low salinity of 20 and $16^{\circ} \mathrm{C}$ was significantly different from almost all other treatments (Fig. 4). Nevertheless, $16^{\circ} \mathrm{C}$ is an unrealistic temperature scenario for Arctic seawater even under forecasted global warming, and thus, the salinity effects on zoospores are not ecologically relevant. In consequence, both zoospores and sporophytes of $A$. esculenta are relatively tolerant to diluted salinities at environmentally significant conditions. As such, the kelp A. esculenta is well adapted to the inflows of melt water into the Kongsfjord during late spring and summer.

Based on the study of Karsten (2007) A. esculenta, Saccharina latissima and Laminaria solidungula were characterized as stenohaline macroalgae. A. esculenta showed a high effective quantum yield between 10 and 50 p.s.u., but bleached and died in 5 p.s.u. media. By contrast, Fucus distichus with a broad salinity tolerance was characterized as euryhaline and Laminaria digitata and Saccorhiza dermatodea as stenohalin-euryhaline. Karsten (2007) hypothesized that acclimation responses of temperate or cold temperate organisms are usually slowed down and so the observed responses of algae can be explained by a temperature-limited physiological capacity. Except for the present study on A. esculenta, interactive effects of salinity and temperature have never been evaluated in polar algae (Karsten 2007). Nevertheless, there are a few, often older studies about effects of salinity and temperature, for example on Fucus vesiculosus (Russell 1987). These experiments indicated that Fucus is evidently much more susceptible to saline changes at extreme temperatures. Another study by Thomas et al. (1988) showed that Cladophora rupestris had a reduced salinity-tolerance range at extreme temperatures, but Cladophora glomerata proved better able to tolerate increased salinity at higher temperatures.

\section{Ecological conclusions}

In summary, the predominant ecological and most influential environmental factor for the kelp A. esculenta is temperature. Temperature is not only responsible for the regulation of metabolism and reproduction but also for the geographical dispersion of kelp species. In both investigated life stages of $A$. esculenta, an upper temperature limit close to $16-20^{\circ} \mathrm{C}$ was determined, which is considerably higher than in the study area of the Kongsfjord. Temperature dominated as an individual effect and interacted synergistically with radiation and salinity. There are cases where plant organisms exposed to a single stress agent were capable of increasing their resistance to subsequent unfavourable impacts (=cross-adaption; reviewed by Alexieva et al. 2003). A trend towards cross-adaptation was detected in sporophytes, where increasing temperature reduced UV effects (Fig. 1). Significant UV inhibition was only observed in algae under the lowest applied temperatures (Fig. 1). More often, the simultaneous influence of several stress factors elevates their deleterious effect, so it considerably exceeds the simple additive effect of their action alone (=cross-synergism; Alexieva et al. 2003). The damaging 
and increasing effects of low salinity at relatively high temperature on germination of A. esculenta zoospores (Fig. 4) indicate a definite cross-synergism.

In an ecological context, and in particular with regard to environmental changes in the Arctic, A. esculenta proved to be tolerant and adaptable to increased temperature, UV radiation and decreased salinity, which are occurring due to global warming and ozone depletion and faster melting of glaciers. These results are only valid up to a relatively unknown species-specific limit. Many more studies on interactive effects, especially on the most sensitive developmental stages of zoospores and gametes and on other kelp species are required for predictions of correlations, specific limits and effects of global change on seaweed-dominated marine coastal ecosystems.

Acknowledgements This study was financially supported by the Helmholtz Society of German Research Centres (project NG-VH059). For collecting samples and assistance on site the authors are deeply grateful to the Scuba divers, and in particular to Max Schwanitz. The authors thank Dr Mirta Teichberg for helpful comments. Furthermore, many thanks go to the International Arctic Environmental Research and Monitoring Facility at Ny Ålesund (Svalbard) for supporting this study. All experiments comply with the current laws of Norway and Germany.

\section{References}

ACIA (2005) Arctic Council and International Arctic Science Committee. Arctic climate impact assessment, Scientific report. Cambridge University Press, Cambridge, p 1042

Alexieva V, Ivanov S, Sergiev I, Karanov E (2003) Interaction between stresses. Bulg J Plant Physiol (Special Issue):1-17

Biebl R (1970) Vergleichende Untersuchungen zur Temperaturresistenz von Meeresalgen entlang der pazifischen Küste Nordamerikas. Protoplasma 69(1):61-83

Bischof K, Hanelt D, Tüg H, Karsten U, Brouwer PEM, Wiencke C (1998) Acclimation of brown algal photosynthesis to ultraviolet radiation in Arctic coastal waters (Spitsbergen, Norway). Polar Biol 20(6):388-395

Bischof K, Hanelt D, Wiencke C (1999) Acclimation of maximal quantum yield of photosynthesis in the brown alga Alaria esculenta under high light and UV radiation. Plant Biol 1:435-444

Bischof K, Peralta G, Kràbs G, Van de Poll WH, Pérez-Llopens JL, Breeman AM (2002) Effects of solar UV-B radiation on camopy structure of Ulva communities from southern Spain. J Exp Bot 53:2411-2421

Bischof K, Gomez I, Molis M, Hanelt D, Karsten U, Lüder U, Roleda MY, Zacher K, Wiencke C (2006) Ultraviolet radiation shapes seaweed communities. Rev Environ Sci Biotechnol 5(2-3):141-166

Bischoff-Bäsmann B (1997) Temperature requirements and biogeography of marine macroalgae-adaptation of marine macroalgae to low temperatures. Rep Polar Res 245:134

Coelho SM, Rijstenbil JW, Brown MT (2000) Impacts of anthropogenic stresses on the early development stages of seaweeds. J Aquat Ecosyst Stress Recovery 7(4):317-333

Davison IR (1991) Environmental effects on algal photosynthesis: temperature. J Phycol 27(1):2-8

Dring MJ, Makarov V, Schoschina E, Lorenz M, Luening K (1996) Influence of ultraviolet-radiation on chlorophyll fluorescence and growth in different life-history stages of three species of Laminaria (Phaeophyta). Mar Biol 126(1):183-191

Fortes MD, Lüning K (1980) Growth rates of North Sea macroalgae in relation to temperature, irradiance and photoperiod. Helgol Meeresunters 34:15-29

Franklin LA, Forster RM (1997) The changing irradiance environment: consequences for marine macrophyte physiology, productivity and ecology. Eur J Phycol 32(3):207-232

Gómez I, Figueroa FL, Sousa-Pinto I, Viñegla B, Pérez-Rodríguez E, Maestre C, Coelho S, Felga A, Pereira R (2001) Effects of UV radiation and temperature on photosynthesis as measured by PAM fluorescence in the red alga Gelidium pulchellum (Turner) Kützing. Bot Mar 44(1):9-16

Hanelt D, Wiencke C, Nultsch W (1997) Influence of UV radiation on the photosynthesis of Arctic macroalgae in the field. J Photochem Photobiol B: Biol 38(1):40-47

Hanelt D, Tüg H, Bischof K, Groß C, Lippert H, Sawall T, Wiencke C (2001) Light regime in an Arctic fjord: a study related to stratospheric ozone depletion as a basis for determination of UV efffects on algal growth. Mar Biol 138(3):649-658

Hoffman JR, Hansen LJ, Klinger T (2003) Interactions between UV radiation and temperature limit inferences from single-factor experiments. J Phycol 39(2):268-272

IPCC (2007) Intergovernmental panel on climate change. Climate change 2007: the physical science basis. Contribution of Working Group I to the fourth assessment. Cambridge University Press, Cambridge, p 996

Karsten U (2007) Research note: salinity tolerance of Arctic kelps from Spitsbergen. Phycol Res 55(4):257-262

Kirst G (1990) Salinity tolerance of eukaryotic marine algae. Annu Rev Plant Physiol Plant Mol Biol 41:21-53

Lüning K (1990) Seaweeds. Their environment, biogeography, and ecophysiology. Wiley, New York, p 527

Müller R, Wiencke C, Bischof K (2008) Interactive effects of UV radiation and temperature on microstages of Laminariales (Phaeophyceae) from the Arctic and North Sea. Climate Res (in press)

Munda IM, Luening K (1977) Growth performance of Alaria esculenta off Helgoland. Helgol Wiss Meeresunters 29(3):311-314

Rautenberger R, Bischof K (2006) Impact of temperature on UV-susceptibility of two Ulva (Chlorophyta) species from Antarctic and Subantarctic regions. Polar Biol 29(11):988-996

Roleda MY, Hanelt D, Wiencke C (2005) Growth kinetics related to physiological parameters in young Saccorhiza dermatodea and Alaria esculenta sporophytes exposed to UV radiation. Polar Biol 28:539-549

Roleda MY, Hanelt D, Wiencke C (2006) Exposure to ultraviolet radiation delays photosynthetic recovery in Arctic kelp zoospores. Photosynth Res 88(3):311-322

Roleda MY, Wiencke C, Hanelt D, Bischof K (2007) Sensitivity of the early life stages of macroalgae from the Northern Hemisphere to ultraviolet radiation. Photochem Photobiol 83(4):851-862

Russell G (1987) Spatial and environmental components of evolutionary change: interactive effects of salinity and temperature on Fucus vesiculosus as an example. Helgol Mar Res 41(3):371-376

Schreiber U, Bilger W, Neubauer C (1994) Chlorophyll fluorescence as a non-intrusive indicator for rapid assessment of in vivo photosynthesis. In: Schulze E-D, Caldwell MM (eds) Ecophysiology of photosynthesis. Ecol Stud Anal Synth 100:49-70

Sokal R, Rohlf FJ (1995) Biometry: the principles and practice of statistics in biological research

Steinhoff FS, Wiencke C, Müller R, Bischof K (2008) Effects of ultraviolet radiation and temperature on the ultrastructure of zoospores of the brown macroalga Laminaria hyperborea. Plant Biol 10(3):388-397 
Steneck RS, Graham MH, Bourque BJ, Corbett D, Erlandson JM, Estes JA, Tegner MJ (2002) Kelp forest ecosystems: biodiversity, stability, resilience and future. Environ Conserv 29(4):436-459

Sundene O (1962) The implications of transplant and culture experiments on the growth and distribution of Alaria esculenta. Nytt Mag Bot 9:155-174

Svendsen H, Beszczynska-Moeller A, Hagen JO, Lefauconnier B, Tverberg V, Gerland S, Oerbaeck JB, Bischof K, Papucci C, Zajaczkowski M, Attolini R, Bruland O, Wiencke C, Winther JG, Dallmann W (2002) The physical environment of KongsfjordKrossfjorden, an Arctic fjord system in Svalbard. Polar Res 21(1):133-166

Swanson AK, Druehl LD (2000) Differential meiospore size and tolerance of ultraviolet light stress within and among kelp species along a depth gradient. Mar Biol 136(4):657-664

Thomas DN, Collins JC, Russell G (1988) Interactive effects of temperature and salinity upon net photosynthesis of Cladophora glomerata (L.) Kuetz. and C. rupestris (L.) Kuetz. Bot Mar 31(1):73-77

tom Dieck (Bartsch) I (1993) Temperature tolerance and survival in darkness of kelp gametophytes (Laminariales, Phaeophyta): ecological and biogeographical implications. Mar Ecol Prog Ser 100:253-264

Veliz K, Edding M, Tala F, Gomez I (2006) Effects of ultraviolet radiation on different life cycle stages of the south Pacific kelps Lessonia nigrescens and $L$. trabeculata (Laminariales, Phaeophytceae). Mar Biol 149(5):1015-1024
Widdowson TB (1971) A taxonomic revision of the genus Alaria Greville. Syesis 4:11-49

Wiencke C (2004a) The coastal ecosystem of Kongsfjord, Svalbard. Synopsis of biological research performed at the Koldewey Station in the years 1991-2003. Alfred-Wegener Institut für Meeres- und Polarforschung, Reports on polar and marine research

Wiencke C, Bartsch I, Bischoff B, Peters AF, Breeman AM (1994) Temperature requirements and biogeography of Antarctic, Arctic and amphiequatorial seaweeds. Bot Mar 37(3):247-259

Wiencke C, Vögele B, Kovaltchouk NA, Hop H (2004b) Species composition and zonation of marine benthic macroalgae at Hansneset in Kongsfjord, Svalbard. In: Wiencke C (ed) The coastal ecosystem of Kongsfjord, Svalbard. Synopsis of biological research performed at the Koldewey Station in the years 1991-2003. Ber Polarforsch Meeresforsch 492:55-62

Wiencke C, Roleda MY, Gruber A, Clayton MN, Bischof K (2006) Susceptibility of zoospores to UV radiation determines upper depth distribution limit of Arctic kelps: evidence through field experiments. J Ecol 94(2):455-463

Wiencke C, Clayton MN, Gómez I, Iken K, Lüder UH, Amsler CD, Karsten U, Hanelt D, Bischof K, Dunton K (2007a) Life strategy, ecophysiology and ecology of seaweeds in polar waters. Rev Environ Sci Biotechnol 6(1-3):95-126

Wiencke C, Lüder UH, Roleda MY (2007b) Impact of ultraviolet radiation on physiology and development of zoospores of the brown alga Alaria esculenta from Spitsbergen. Physiol Plant 130(4):601-612 